\title{
ANALYSIS OF SYSTEM AND SERVICE MANAGEMENT IMPROVEMENT FOR MENTAL HEALTH AT MENTAL HOSPITALS: A SYSTEMATIC REVIEW
}

\author{
Dede Suryaputra ${ }^{1)}$, Wibowo Adik²) \\ 1)Masters Program in Faculty of Public Health, Universitas Indonesia \\ ${ }^{2)}$ Department of Policy and Health Administration, Faculty of Public Health, \\ Universitas Indonesia
}

\begin{abstract}
Background: Mental disorders are common worldwide, but the quality of care for mental health has not increased to the same extent. Poor quality mental health services can lead to negative therapeutic outcomes. However, poor quality of care can be substantially redressed through concerted and systematic quality improvement strategies. This study aimed to review systematically the system and service management improvement for mental health at mental hospitals.

Subjects and Method: A systematic review was conducted by searching following databases included EBSCOhost, ProQuest, PubMed, Google Scholar, Science Direct, and Online Library. The keywords were "system improvement" AND "management health services" AND "mental health" AND "hospital". The inclusion criteria were English and open access. After review process, 30 articles were included in this review.

Results: System improvement and management of mental health services reduced the number of patients with chronic mental disorder in hospitals. Emergency visit decreased with prescription of 2 or more antipsychotics. System improvement and management services increased patient satisfaction.

Conclusion: System improvement and management of mental health services increase patient satisfaction.
\end{abstract}

Keywords: system improvement, management, mental health, service, patient satisfaction

\section{Correspondence:}

Dede Suryaputra. Masters Program in Faculty of Public Health, Universitas Indonesia, Depok, West Java. Email: dede.suryaputra97@gmail.com. Mobile: 081511034600.

The $6^{\text {th }}$ International Conference on Public Health

Best Western Premier Hotel, Solo, Indonesia, October 23-24, 2019 | 293

https://doi.org/10.26911/the6thicph.04.55 